\title{
FAKTOR PENYEBAB ANEMIA DEFISIENSI BESI PADA IBU HAMIL DI WILAYAH KERJA PUSKESMAS BONGO NOL KABUPATEN BOALEMO
}

\author{
Sunarto Kadir \\ Fakultas Olahraga dan Kesehatan, Univeristas Negeri Gorontalo \\ E-mail: sunarto.kadir@yahoo.co.id
}

\begin{abstract}
ABSTRAK
Ibu hamil merupakan salah satu kelompok berisiko tinggi terhadap masalah gizi terutama anemia defisiensi besi, karena kebutuhan zat besi (Fe) meningkat secara signifikan selama kehamilan. Salah satu faktor penyebab masih tingginya anemia defisiensi besi pada ibu hamil adalah rendahnya kepatuhan ibu hamil dalam mengkonsumsi tablet Fe. Penelitian ini dilakukan pada ibu hamil risiko tinggi di wilayah kerja Puskesmas Bongo Nol Kabupaten Boalemo. Tujuan penelitian adalah untuk mengetahui hubungan kepatuhan ibu hamil dalam mengkonsumsi zat besi dengan kejadian anemia. Jenis penelitian yang digunakan adalah observasional analitik dengan pendekatan cross sectional. Populasi adalah seluruh ibu hamil yang datang memeriksakan kehamilannya dan memperoleh tablet Fe di Wilayah Kerja Puskesmas Bongo Nol Kecamatan Paguyaman Kabupaten Boalemo yang berjumlah 99 orang. Sampel diperoleh sebanyak 56 orang yang diambil dengan menggunakan teknik purposive sampling. Data dikumpulkan melalui metode wawancara dengan instrumen berupa lembar observasi. Analisis data menggunakan uji Chi-Square. Hasil penelitian menunjukan bahwa sebagian besar ibu hamil tidak patuh dalam mengkonsumsi zat besi yakni berjumlah 35 orang $(62,50 \%)$, kejadian anemia pada ibu hamil berjumlah 36 orang $(64,29 \%)$, dan terdapat hubungan yang signifikan antara kepatuhan ibu hamil dalam mengkonsumsi zat besi dengan kejadian anemia $(p=0,044)$. Disarankan kepada pihak puskesmas dan tenaga kesehatan agar mengoptimalkan kegiatan sosialisasi tentang pentingnya konsumsi zat besi pada ibu hamil risiko tinggi.
\end{abstract}

Kata Kunci: Anemia, Defisiensi Zat Besi (Fe), Ibu Hamil

\begin{abstract}
Pregnant women are one of the groups at high risk for nutritional problems, especially iron deficiency anemia, because the need for iron (Fe) increases significantly during pregnancy. One of the factors causing the still high iron deficiency anemia in pregnant women is the low compliance of pregnant women in consuming Fe tablets. This research was conducted in high-risk pregnant women in the working area of Balemo Zero Health Center in Boalemo Regency. The purpose of the study was to determine the relationship of adherence of pregnant women to consume iron with the incidence of anemia. The type of research used was observational analytic with cross sectional approach. The population was all pregnant women who came to have their pregnancies examined and obtained Fe tablets in the Bongo Nol Health Center Working Area in Paguyaman District, Boalemo Regency, amounting to 99 people. Samples were obtained as many as 56 people taken using the purposive sampling technique. Data were collected through interview methods with instruments in the form of observation sheets. Data analysis using Chi-Square test. The results showed that most pregnant women did not adhere to consuming iron, amounting to 35 people (62.50\%), the incidence of anemia in pregnant women amounted to 36 people $(64.29 \%)$, and there was a significant relationship between adherence of pregnant women in consume iron with the incidence of anemia $(p=0.044)$. It is recommended to the health center and health workers to optimize socialization activities about the importance of iron consumption in high-risk pregnant women.
\end{abstract}

Keywords: Iron (Fe) Deficiency, Pregnant Women, Anemia 


\section{PENDAHULUAN}

Berdasarkan data World Health Organization (WHO) setiap tahunnya sekitar 14.180 perempuan Indonesia meninggal karena hamil dan melahirkan. Sedangkan di dunia mencapai lebih 500 ribu orang. (Syafrudin, 2007). Wanita hamil merupakan salah satu kelompok yang rentan masalah gizi terutama anemia defisiensi besi $(\mathrm{Fe})$. Wanita hamil berisiko tinggi mengalami anemia defisiensi besi karena kebutuhan zat besi meningkat secara signifikan selama kehamilan. Pada masa kehamilan zat besi yang dibutuhkan oleh tubuh lebih banyak dibandingkan saat tidak hamil menginjak triwulan kedua sampai dengan triwulan ketiga. Pada triwulan pertama kehamilan kebutuhan zat besi lebih rendah disebabkan jumlah zat besi yang ditransfer ke janin masih rendah (Waryana, 2010).

Anemia merupakan kondisi dimana berkurangnya sel darah merah (eritrosit) dalam sirkulasi darah atau massa hemoglobin sehingga tidak mampu memenuhi fungsinya sebagai pembawa oksigen ke seluruh jaringan. Prevalensi anemia pada ibu hamil di Indonesia adalah $70 \%$, atau 7 dari 10 wanita hamil menderita anemia.

Menurut Soeprono (2008) bahwa dampak anemia pada kehamilan bervariasi dari keluhan yang sangat ringan hingga terjadi gangguan kelangsungan kehamilan (abortus, partus imatur/premature), gangguan proses persalinan (intertia atonia uterus, partus lama, trias perdarahan), gangguan pada masa nipas (sub involusi rahim, daya tahan terhadap infeksidan stres kurang, produksi ASI rendah), dan gangguan pada janin (abortus, dismaturitas, mikrosomi, berat badan lahir rendah, kematian perinatal).

Salah satu faktor penyebab masih tingginya anemia defisiensi besi pada ibu hamil adalah rendahnya kepatuhan ibu hamil dalam mengkonsumsi tablet Fe. Yunita (2011) mengatakan bahwa ketidakpatuhan ibu hamil mengkonsumsi tablet Fe dapat mencerminkan seberapa besar peluang untuk terkena anemia. Berdasarkan hasil Riset Kesehatan Dasar (Riskesdas) tahun 2013 menunjukkan bahwa mengkonsumsi tablet $\mathrm{Fe}$ selama kehamilan di Indonesia sebesar $89,1 \%$. Ibu hamil yang mengkonsumsi tablet $\mathrm{Fe} 90$ hari selama kehamilan sebesar 33,3\%. Ibu hamil yang mengkonsumsi tablet $\mathrm{Fe}$ kurang dari 90 hari sebesar $34,4 \%$ dan sebesar 21,4\% yang tidak mengkonsumsi tablet Fe 90.
Jumlah kematian ibu di Provinsi Gorontalo pada tahun 2014 mencapai 39 jiwa, jumlah ini menurun dibandingkan dengan kematian ibu di tahun 2013 yakni mencapai 52 jiwa. Untuk Provinsi Gorontalo belum dapat menghitung angka kematian ibu dikarenakan jumlah kelahiran belum mencapai 100.000 kelahiran hidup, sedangkan trend kematian ibu di Provinsi Gorontalo dari kurun waktu tahun 2010 hingga 2014, dimana 40 jiwa mati di tahun 2010, meningkat 49 jiwa di tahun 2011, hingga tahun 2013 meningkat lagi menjadi 52 jiwa, dan di tahun 2014 angka ini mengalami penurunan yakni sebanyak 39 kematian ibu (Dinas Kesehatan Provinsi Gorontalo, 2014).

Penyebab kematian ibu di atas yakni pendarahan, hipertensi saat hamil atau preklamsia dan infeksi. Pendarahan menempati persentase tetinggi penyebab kematian ibu $(25,6 \%)$, anemia dan kekurangan energi kronis (KEK) pada ibu hamil menjadi penyebab utama terjadinya perdarahan dan infeksi yang merupakan faktor kematian utama ibu. Berdasarkan data dari Puskesmas Bongo Nol Kecamatan Paguyaman Kabupaten Boalemo diketahui bahwa pada bulan Januari-Juni 2017 terdapat 99 orang ibu hamil, dimana yang mengalami anemia sebanyak 25 orang $(25,25 \%)$. Penelitian ini bertujuan untuk mengetahui hubungan kepatuhan ibu hamil dalam mengkonsumsi zat besi dengan kejadian anemia.

\section{METODE PENELITIAN}

Penelitian ini dilaksanakan di wilayah kerja Puskesmas Bongo Nol Kecamatan Paguyaman Kabupaten Boalemo pada tanggal 12 Januari 2018 sampai dengan 4 Februari 2018. Jenis penelitian yang digunakan adalah observasional analitik dengan pendekatan cross sectional di mana penelitian ini diukur secara bersamaan antara variabel independen (kepatuhan ibu hamil mengkonsumsi zat besi) dan variabel dependen (kejadian anemia). Populasi adalah seluruh ibu hamil yang datang memeriksakan kehamilannya dan mendapat tablet Fe di Wilayah Kerja Puskesmas Bongo Nol Kecamatan Paguyaman Kabupaten Boalemo dengan jumlah 99 orang. Sampel diperoleh sebanyak 56 orang yang diambil dengan menggunakan teknik purposive sampling, dengan kriteria sebagai berikut:

a. Ibu hamil berada pada trimester II dan III yang memeriksakan kehamilannya di wilayah kerja Puskesmas Bongo Nol 
Kecamatan Paguyaman Kabupaten Boalemo

b. Ibu hamil yang memperoleh tablet $\mathrm{Fe}$ Data dikumpulkan melalui metode wawancara dengan instrumen berupa lembar observasi untuk selanjutnya dianalisis menggunakan uji Chi-Square.

\section{HASIL PENELITIAN}

a. Usia Ibu Hamil

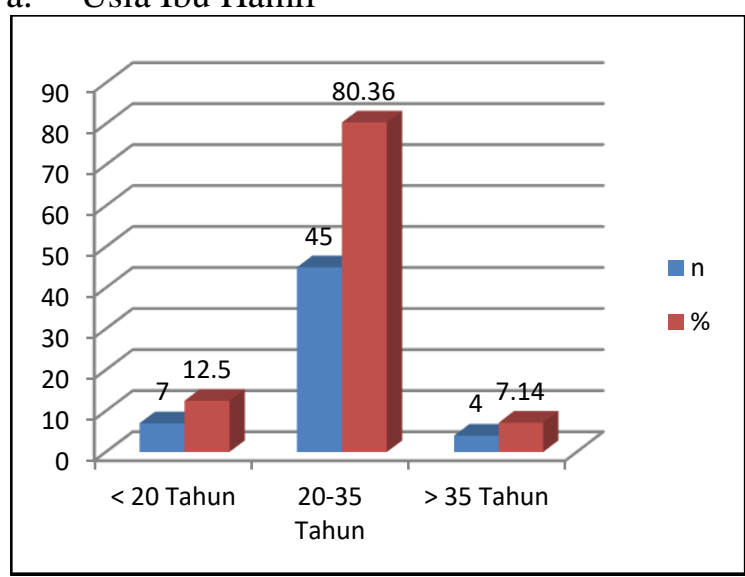

Gambar 3.1 Usia Ibu Hamil

Berdasarkan Gambar 3.1 bahwa responden paling banyak berusia 20-35 tahun yakni 45 orang $(80,36 \%)$, dan paling sedikit pada umur $\geq 35$ tahun yakni 4 orang $(7,14 \%)$. Hal ini menunjukan bahwa responden paling banyak pada usia ideal dan termasuk pada usia kesuburan, sedangkan pada usia-usia berikutnya akan mengurangi penurunan kesuburan.

b. Usia Kehamilan Ibu

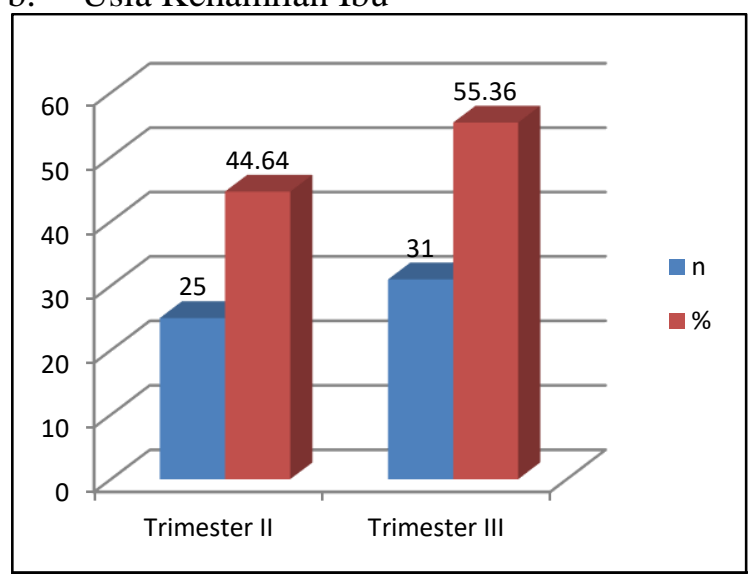

Gambar 3.2 Usia Kehamilan Ibu

Berdasarkan Gambar 3.2 bahwa paling banyak responden berada pada trimester III berjumlah 31 orang $(55,36 \%)$ dan paling sedikit pada trimester II yakni 25 orang $(44,64 \%)$. c. Karakteristik Paritas

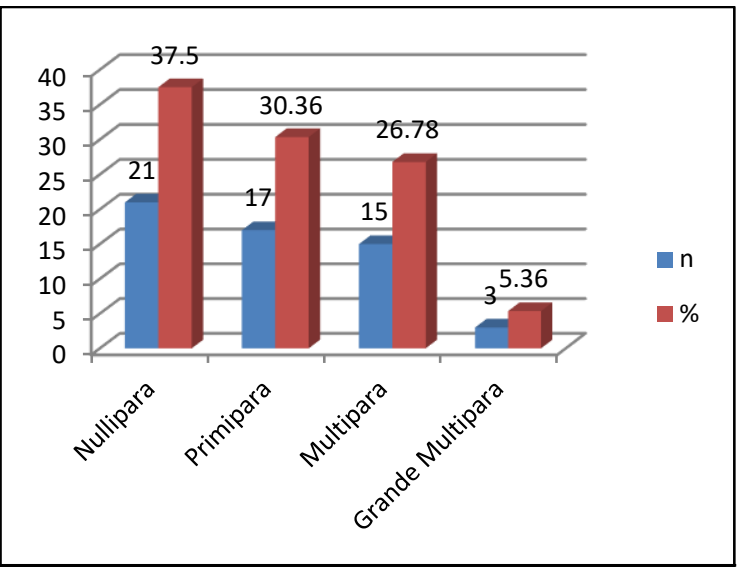

Gambar 3.3 Karakteristik Paritas

Berdasarkan Gambar 3.3 bahwa paling banyak responden nullipara (hamil anak pertama) yakni 21 orang $(37,50 \%)$, dan paling sedikit responden grande multipara (memiliki anak lebih atau sama dengan 5) yakni 3 orang $(5,36 \%)$. Kehamilan yang pertama kali perlu mendapatkan perhatian khusus karena ibu belum memiliki pengalaman untuk menjaga kesehatan kehamilannya.

d. Hubungan Kepatuhan Ibu Hamil dalam Mengkonsumsi Zat Besi dengan Kejadian Anemia

Tabel 3.1 Tabulasi Silang Variabel Kepatuhan Ibu Hamil dalam Mengkonsumsi Zat Besi dengan Kejadian Anemia

\begin{tabular}{|c|c|c|c|c|c|c|c|}
\hline \multirow{3}{*}{ Kepatuhan } & \multicolumn{4}{|c|}{ Kejadian Anemia } & \multirow{2}{*}{\multicolumn{2}{|c|}{ Total }} & \multirow{3}{*}{$\begin{array}{c}p- \\
\text { value }\end{array}$} \\
\hline & \multicolumn{2}{|c|}{ Anemia } & \multicolumn{2}{|c|}{$\begin{array}{c}\text { Tidak } \\
\text { Anemia }\end{array}$} & & & \\
\hline & $\mathrm{n}$ & $\%$ & $\mathrm{n}$ & $\%$ & $\mathrm{n}$ & $\%$ & \\
\hline Patuh & 10 & 17,9 & 11 & 19,6 & 21 & 37,5 & \\
\hline $\begin{array}{l}\text { Tidak } \\
\text { Patuh }\end{array}$ & 26 & 46,4 & 9 & 16,1 & 35 & 62,5 & 0,044 \\
\hline Total & 36 & 64,3 & 20 & 35,7 & 56 & 100 & \\
\hline
\end{tabular}

Sumber : Data Primer, 2018

Berdasarkan Tabel 3.1 bahwa paling banyak responden yang tidak patuh dalam mengkonsumsi zat besi yakni 35 orang $(62,5 \%)$, dari jumlah tersebut 26 orang $(46,4 \%)$ mengalami anemia dan 9 orang $(16,1 \%)$ tidak mengalami anemia. Sedangkan paling sedikit yang patuh dalam mengkonsumsi zat besi yakni 21 orang $(37,5 \%)$, dari jumlah tersebut 10 orang $(17,9 \%)$ mengalami anemia, dan sejumlah 11 orang tidak mengalami anemia (19,6\%). Dari hasil uji Chi-Square diperoleh nilai $\mathrm{p}=0.044 \quad(\mathrm{p}<0.05)$, artinya terdapat hubungan yang signifikan antara kepatuhan ibu hamil dalam mengkonsumsi zat besi dengan 
kejadian anemia di wilayah kerja Puskesmas Bongo Nol Kabupaten Boalemo.

\section{PEMBAHASAN}

Usia merupakan salah satu faktor yang dapat menggambarkan kematangan seseorang baik fisik, psikis, maupun sosial, sehingga membantu seseorang dalam pengetahuannya, semakin bertambah umur, semakin bertambah pula pengetahuan yang didapat. Dalam penelitian ini sebagian besar ibu hamil berusia 20-35 tahun yang merupakan usia reproduksi yang baik, dimana usia tersebut merupakan periode baik untuk hamil, melahirkan dan menyusui. Umur ibu yang tidak dalam keadaan reproduksi sehat dimana kehamilan terjadi pada usia < 20 tahun dan > 35 tahun. Mereka lebih berisiko terkena hipertensi atau anemia dan melahirkan bayi dengan berat lahir rendah.

Kepatuhan ibu hamil dalam mengkonsumsi tablet $\mathrm{Fe}$ sering menjadi masalah karena kepatuhan sangat sulit untuk diterapkan pada diri sendiri, apalagi untuk orang lain, sehingga banyak ibu hamil yang kurang patuh dalam mengkonsumsi zat besi. Hasil penelitian menunjukan bahwa sebagian besar ibu hamil tidak patuh mengkonsumsi zat besi, hal tersebut dapat disebabkan oleh karena kurangnya informasi tentang zat besi yang diberikan oleh petugas kesehatan.

Banyaknya ibu hamil yang tidak patuh tersebut dapat dipengaruhi oleh efek samping yang kurang nyaman dirasakan oleh ibu ketika mengkonsumsi zat besi, seperti mual muntah, dan nyeri ulu hati. Hal tersebut menyebabkan ibu hamil menjadi kurang/tidak patuh dalam mengkonsumsi tablet $\mathrm{Fe}$ sehingga menyebabkan anemia. Alasan lain yaitu mereka lupa, malas, dan bosan jika setiap hari harus mengkonsumsi zat besi tersebut. Hal ini sesuai dengan pernyataan Hidayah (2012) bahwa suplemen oral zat besi dapat menyebabkan mual muntah, nyeri ulu hati dan konstipasi. Namun derajat mual yang ditimbulkan oleh setiap preparat tergantung pada jumlah elemen zat besi yang diserap. Takaran zat besi diatas $60 \mathrm{mg}$ dapat menimbukan efek samping yang tidak bisa diterima pada ibu hamil sehingga terjadi ketidakpatuhan dalam pemakai obat. Ibu hamil perlu mengkonsumsi zat besi selama kehamilan, karena kebutuhan zat besi ibu hamil meningkat selama kehamilan.

Untuk meningkatkan kepatuhan ibu hamil dalam mengonsumsi zat besi, maka petugas kesehatan harus mengikutsertakan keluarga dalam pengawasan minum obat. Pengawasan minum obat merupakan kegiatan yang dilakukan untuk menjamin kepatuhaan minun obat sesuai dengan dosis dan jadwal seperti yang telah ditetapkan. Pendapat ini sejalan dengan teori yang dikemukakan oleh Wiradyani (2013) bahwa keluarga mempunyai peran yang signifikan dalam mendukung ibu untuk mengonsumsi tablet $\mathrm{Fe}$ secara rutin. Ibu seringkali lupa untuk minum tablet $\mathrm{Fe}$ secara rutin bahkan berhenti untuk mengonsumsinya bila tidak ada dukungan dari keluarganya.

Anemia dalam kehamilan adalah kondisi ibu dengan kadar Hemoglobin di bawah 11 gr pada trimester 1 dan 3. Perubahan fisiologi yang alami terjadi selama kehamilan akan mempengaruhi jumlah sel darah normal pada kehamilan. Peningkatan volume darah ibu terutama terjadi akibat peningkatan jumlah sel darah merah di dalam sirkulasi, tetapi jumlahnya seimbang dengan peningkatan volume plasma. Ketidakseimbangan ini akan terlihat dalam bentuk penurunan kadar $\mathrm{Hb}$. Dalam penelitian ini kejadian anemia diukur menggunakan alat Hemoglobinometer (Hemometer) Sahli.

Anemia dalam kehamilan memberikan pengaruh yang kurang baik bagi ibu maupun janin, karena dapat berpengaruh pada perkembangan janin selama kehamilan. Selain itu dapat pula mengakibatkan kelahiran premature, penyakit infeksi bahkan dapat menyebabkan kematian pada ibu dan janin. Sehingga dalam hal ini perlu adanya upaya dalam mencegah terjadinya anemia bagi ibu hamil.

Hasil penelitian terhadap responden yang patuh tetapi mengalami anemia, hal ini dikarenakan ada beberapa faktor yang dapat mempengaruhi kadar $\mathrm{Hb}$ ibu hamil. Salah satu faktor yang mempengaruhi terjadinya anemia pada ibu hamil yakni pengetahuan ibu hamil terhadap ketidakpatuhan dalam mengkonsumsi zat besi. Oleh karena itu pengetahuan ibu hamil tentang zat besi yang tinggi dapat membentuk sikap yang positif terhadap kepatuhan ibu hamil dalam mengkonsumsi zat besi. Tanpa adanya pengetahuan tentang zat besi, maka sulit untuk menanamakan kebiasaan dalam menggunakan bahan makanan sumber zat besi yang penting bagi ibu hamil. Kurangnya pengetahuan sering dijumpai sebagai faktor yang penting dalam masalah defisensi zat besi. Hal ini dapat terjadi karena masyarakat kurang mampu dalam menerapkan informasi tentang tablet $\mathrm{Fe}$ dalam 
kehidupan sehari-hari. Semakin tinggi pengetahuan ibu hamil tentang zat besi, maka akan semakin patuh dalam mengkonsumsi tablet Fe serta dalam pemilihan makanan.

Selain itu pendidikan juga mempengaruhi dalam penentu kadar Hb. Dalam penelitian ini tingkat pendidikan mempengaruhi tingkat kejadian anemia, semakin tinggi tingkat pendidikannya semakin rendah pula resiko terkena anemia, karena tingkat pendidikan turut menentu mudah tidaknya seseorang menyerap dan memahami pengetahuan gizi yang mereka peroleh. Semakin baik pendidikan ibu hamil, maka dalam menyerap informasi yang diterima semakin baik khususnya tentang manfaat tablet $\mathrm{Fe}$, hal ini berdampak pada kepatuhan ibu hamil dalam menkonsumsi tablet Fe karena disitu ibu hamil mengetahui manfaat dari tablet Fe bagi ibu hamil (Arisman, 2004).

Terdapat hubungan antara kepatuhan ibu hamil dalam mengkonsumsi zat besi (Fe) dengan kejadian anemia di wilayah kerja Puskesmas Bongo Nol Kabupaten Boalemo. Hal ini sejalan dengan Proverawati (2009), yang mengatakan bahwa anemia dalam kehamilan didefinisikan sebagai penurunan kadar hemoglobin dalam darah kurang dari 11 g/dl selama masa kehamilan. Kehamilan memerlukan tambahan zat untuk meningkatkan jumlah sel darah merah dan membentuk sel darah merah janin dan plasenta. Selama hamil volume darah meningkat $50 \%$ dari 4 ke $6 \mathrm{~L}$, volume plasma meningkat sedikit menyebabkan penurunan kosentrasi $\mathrm{Hb}$ dan nilai hematokrit. Penurunan ini lebih kecil pada ibu hamil yang mengkonsumsi zat besi.

Selain itu penelitian Hidayah (2012) di Kabupaten Banyumas menunjukan bahwa ibu hamil yang mengalami anemia karena tidak patuh mengkonsumsi tablet $\mathrm{Fe}(62,5 \%)$, lebih banyak dibandingkan yang patuh mengkonsumsi tablet $\mathrm{Fe} \quad(37,3 \%)$. Serta didukung oleh penelitian yang dilakukan oleh Gustiani (2014) di wilayah kerja UPDT Puskesmas Cigeureung Kota Tasikmalaya mengatakan bahwa kejadian anemia disebabkan karena ketidakpatuhan konsumsi tablet besi $(79,6 \%)$ lebih banyak dibandingkan dengan ibu hamil yang tidak anemia karena ketidakpatuhan $(20,4 \%)$.

Oleh karena itu kejadian anemia dapat dihindari dengan patuh mengkonsumsi zat besi sesuai dengan aturan, selain itu juga bisa didukung dengan pemenuhan nutrisi yang berasal dari makanan yang dikonsumsi dan juga menghindari faktor risiko terjadinya anemia.

\section{SIMPULAN DAN SARAN}

Ibu hamil paling banyak tidak patuh dalam mengkonsumsi zat besi yakni 35 orang $(62,5 \%)$, dimana ada 26 orang $(46,4 \%)$ mengalami anemia dan 9 orang $(16,1 \%)$ tidak mengalami anemia. Ada hubungan yang signifikan antara kepatuhan ibu hamil dalam mengkonsumsi zat besi $(\mathrm{Fe})$ dengan kejadian anemia. Disarankan bagi puskesmas dan tenaga kesehatan mengoptimalkan sosialisasi mengenai pentingnya zat besi terutama kepada ibu hamil yang berada dalam kategori risiko tinggi.

\section{REFERENSI}

Arisman. 2004. Gizi Dalam Daur Kehidupan. Jakarta: EGC.

Dinas Kesehatan Provinsi Gorontalo. 2014. Profil Kesehatan.

Gustiani, D. 2014. Hubungan Mengkonsumsi Tablet Besi (Fe) terhadap Kejadian Anemia pada Ibu Hamil di Wilayah Kerja UPTD Puskesmas Cigeureung Kota Tasikmalaya.Universitas Siliwangi.

Hidayah, W. 2012. Hubungan Kepatuhan Ibu Hamil Mengkonsumsi Tablet Fe dengan Kejadian Anemia di Desa Pengeraji Kecamatan Cilongok Kabupaten Bayunmas. Jurnal Ilmiah Kebidanan.

Proverawati, A. 2009. Anemia dan Anemia Kehamilan. Yogyakarta: Nuha Medika.

Soeprono. 2008. Anemia pada Wanita Hamil. Berkala Ilmu Kedokteran Fakultas Kedokteran Universitas Gaja Mada.

Syafrudin, H. 2007. Buku Acuan Nasional Pelayanan Kesehatan Maternal dan Neonatal. Jakarta: EGC.

Waryana. 2010. Nutrisi Janin dan Ibu Hamil. Yogyakarta Nuha Medika.

Wiradyani. 2013. Faktor-faktor yang Berhubungan dengan Kepatuhan Ibu Mengkonsumsi Tablet Besi-Folat Selama Kehamilan. Jurnal Gizi dan Pangan.

Yunita, A. 2011. Pengaruh Penyuluhan Pada Ibu Hamil Tentang Anemia Terhadap Tingkat Pengetahuan Tentang Anemia di Desa Sambirejo Kecamatan Plupuh. Surakarta: Fakultas Kedokteran Universitas Sebelas Maret. 